\title{
INFLUENCE OF SERVICE QUALITY TO CUSTOMER SATISFACTION PT. POS INDONESIA KARAWANG BRANCH
}

\author{
Asep Maulana \\ Fakultas Ekonomi Dan Bisnis Univesitas Negeri Singaperbangsan Karawang \\ asep.maulana@fe.unsika.ac.id \\ Evi Pebriyanti \\ Fakultas Ekonomi Dan Bisnis Univesitas Negeri Singaperbangsan Karawang \\ evi.pebriyanti16140@student.unsika.ac.id \\ Evi Depiana \\ Fakultas Ekonomi Dan Bisnis Univesitas Negeri Singaperbangsan Karawang \\ evi.depiana16139@student.unsika.ac.id \\ Eriena Eka Wardani \\ Fakultas Ekonomi Dan Bisnis Univesitas Negeri Singaperbangsan Karawang \\ eriena.eka16132@student.unsika.ac.id \\ Elfa Alfiani \\ Fakultas Ekonomi Dan Bisnis Univesitas Negeri Singaperbangsan Karawang \\ elfa.alfiani16127@student.unsika.ac.id \\ Dwino Ayenero \\ Fakultas Ekonomi Dan Bisnis Univesitas Negeri Singaperbangsan Karawang \\ nerodwino@gmail.com
}

\begin{abstract}
PT Pos Indonesia is still less demanded by society so that the number of deliveries by PT POS Indonesia every year Indonesia is unstable. The problem in this research is to know the effect of quality of services on customer satisfaction PT Pos Indonesia. Quality has a close correlation with customer satisfaction to establish a strong relationships with a company. The research methods used in this research is a quantitative method with data collection through questionnaires given to 100 people who have or often use Indonesia Postal delivery service. The questionnaire data becomes the primary data source that is processed using IBM SPSS statistical software 24. Based on the results of data processed through IBM SPSS statistical software 24, it can be seen that the effect of Quality of Service on Customer Satisfaction is $41.5 \%$ while $58.5 \%$ is influenced by other free variables.
\end{abstract}

Keywords: marketing services, services, customer satisfaction.

\section{Abstrak}

Jasa kurir Pos Indonesia masih kurang diminati oleh masyarakat sehingga jumlah pengiriman Pos Indonesia setiap tahunnya tidak stabil. Permasalahan dalam penelitian ini adalah mengetahui pengaruh kualitas pelayanan jasa terhadap kepuasan pelanggan PT. Pos Indonesia. Kualitas memiliki hubungan yang erat dengan kepuasan pelanggan untuk menjalin hubungan yang kuat dengan perusahaan. Metode penelitian yang digunakan dalam penelitian ini adalah metode kuantitatif denganpengumpulan data melalui penyebaran kuesioner yang diberikan kepada 100 orang yang pernah atau sering mengunakan jasa pengiriman Pos 
Indonesia. Data kuesioner tersebut menjadi sumber data primer yang diolah menggunakan sofware IBM SPSS statistic 24. Berdasarkan hasil data yang diolah melalui sofware IBM SPSS statistic 24 dapat diketahui bahwa pengaruh Kualitas Pelayanan Jasa terhadap Kepuasan Pelanggan sebesar 41,5\% sedangkan 58,5\% dipengaruhi oleh variabel bebas lainnya

Kata Kunci: pemasaran jasa, pelayanan jasa, kepuasan pelanggan. JEL: M30

\section{Research Background}

The increasing number of competitors together with the intensity of completion make a company must always pay attention to customer needs and desires, as well customer expectations by providing services that are offered by competitors. Additionally, customers are increasingly selective with regard to choice of products to be used or consumed (Sulistyawati and Seminari 2015).

Changes and developments in the field of technology bring considerable impact on various fields that is followed by world economy, from industrial economy to service economy. One of these is technological development that is able to send and receive goods more easily, quickly, and securely. Delivery service, over the years, increasingly becomes consideration of the wider community. The number of shipping service companies that emerged make owner or manager of the companies should be able to create strategies in order capable to compete and more superior than their competitors (Azis 2016).

Business of courier service or delivery of goods or shipping service is growing very fast in Indonesia. The courier service that has been in the business very long is PT Pos Indonesia, a company owned by the Government of Indonesia. Later, there were many private sector companies that pioneered the private courier or delivery service, like TIKI, JNE and DHL. Courier service companies then are competing by offering their courier / delivery services with all their advantages that have been considered having competitive advantages. The main factor is in superiority, i.e. Services (Rahmayanti and Suryawardani 2014).

Quality of service is becoming very important (for PT Pos Indonesia) to win the competition. Understanding what the quality of service shall be provided to customer desire and expectation will be an added value for the company (PT Pos Indonesia). Quality of service needs to pay attention of these because the Ministry (of BUMN, the Indonesia Government's entity owned the company), has direct relationship with the ability to compete and the level of corporate profits (Effendi and Yuliati 2016).

Quality has a correlation with the customer satisfaction to establish strong relationships with a company. In the long term the bond allows a company to carefully understand customer expectations and needs. One of the factors that affect customer preference is namely the quality of service. In the field of services, the quality of service is mainly about customer satisfaction, i.e., customer will be satisfied if they get goods or services as expected.

The growing numbers of people that use the delivery / courier / shipping services make quality of service then become very important to win the competition. Companies need to start thinking about the importance of service so that the company is better, because the quality of service is very important to improve customer satisfaction.

PT Pos Indonesia, better known as the post office or "kantor pos" in Bahasa is one of the business entities doing business in the field of delivery of the goods. This post office was first established in Batavia by Governor General G. W Baron Van Imhoff, on 26 August 1746. The post office was founded with the aim to provide security for letters of Batavia residents at that time. Then, the postal service became instrumental to provide service to people who want to send mails (Pos Indonesia 2018).

Nowadays, PT Pos Indonesia has shown creativity by collaborating with the online marketer for sending goods through PT Pos Indonesia, such that PT Pos Indonesia sends not 
only mails but also goods. Nevertheless, the kind services provided by PT Pos Indonesia are still less considered by the public due to perception that sending goods through post office is considered ineffective and inadequate. One complain that is commonly raised by customers is the loss of the goods during delivery. This kind of complaint makes customers feel less trusting PT Pos Indonesia and switch to other delivery services (Indah dan Suryoko 2015).

Table 1. Indonesia Courier Service Market Share Year 2015-2017

\begin{tabular}{cccc}
\hline Company & 2015 & 2016 & 2017 \\
\hline JNE & $43,5 \%$ & $47,6 \%$ & $49,4 \%$ \\
TIKI & $36,2 \%$ & $35,7 \%$ & $34,7 \%$ \\
Pos Indonesia & $15,0 \%$ & $35,0 \%$ & $35,0 \%$ \\
DHL & $2,1 \%$ & $1,3 \%$ & $1,3 \%$ \\
\hline
\end{tabular}

Source: www.posindonesia.com (accessed on 12 October 2018, 20.07).

Regarding market share, Table 1 shows that JNE is superior compared to other courier service companies having market share in 2015-2017 has been steadily on top and increased. While Pos Indonesia is steadily ranked $3^{\text {rd }}$. PT Pos Indonsia increased its market share from 2015 to 2016, but from 2016 to 2017 its market share remains stable in 35\% figure. This is caused by other courier service companies that are better than Pos Indonesia.

PT Pos Indonesia is Indonesia's first courier service company. Also, PT Pos Indonesia was once awarded the Indonesia Domestic Express Service Provider of the Year Award year 2017 (Pos Indonesia 2018). The award received by Post Indonesia make Post Indonesia became one of the courier service considered by the public, although it remain ranked $3^{\text {rd }}$ in term of Top Brand; refer to the following data Top Brand Index:

Table 2. Top Brand Index Courier Service in Indonesia Year 2012-2017

\begin{tabular}{ccccccc}
\hline \multirow{2}{*}{ Brand } & \multirow{6}{c}{ TBI } & \multicolumn{2}{c}{2016} & 2017 \\
\hline TIKI & $59.6 \%$ & $53.7 \%$ & $45.1 \%$ & $43.5 \%$ & $35.7 \%$ & $35.7 \%$ \\
JNE & $21.2 \%$ & $28.6 \%$ & $33.2 \%$ & $36.2 \%$ & $47.6 \%$ & $45.0 \%$ \\
POS & & & & & & \\
INDONESIA & $7.3 \%$ & $8.4 \%$ & $8.4 \%$ & $6.7 \%$ & $9.6 \%$ & $11.6 \%$ \\
DHL & $3.1 \%$ & $4.0 \%$ & $5.5 \%$ & $2.1 \%$ & $1.3 \%$ & $3.5 \%$ \\
\hline
\end{tabular}

Source: www.posindonesia.com; accessed on 21 October 2018, 21.20

Table 2 shows that TIKI and JNE still maintain their rank as top brands, in which TIKI and JNE were ranked 1st and 2nd, respectively. PT Pos Indonesia is ranked 3rd. Although PT Pos Indonesia is not heading the top brands, PT Pos Indonesia every year experience escalation in term of public recognition as top brands. PT Pos Indonesia should maintain its rank by increasing customer satisfaction by providing service in accordance with customer wishes and needs.

PT Pos Indonesia was the first courier service business in Indonesia, but still many 
people are less interest to use the delivery services offered by the company. The following is Pos Indonesia's postal delivery data from the year 2012 until 2017.

Table 3. Delivery by Pos Indonesia Years 2012-2017

\begin{tabular}{ccccccc}
\hline \multirow{2}{*}{ Package/ Product Name } & 2012 & 2013 & 2014 & 2015 & 2016 & 2017 \\
\hline Paket Standar & 7405 & 6971 & 6524 & 2099 & 2738 & 2871 \\
Paket Kilat Khusus & 3801 & 4114 & 6106 & 2056 & 1447 & 8689 \\
Paket Biasa LN & 89 & 109 & 51 & 183 & 17 & 19 \\
Paket Cepat LN & 48 & 64 & 83 & 18 & 19 & 38 \\
Remailing & 7095 & 2912 & & & 599 & \\
EMS & 13001 & 17622 & 12497 & 522 & 382 & 415 \\
JUMLAH & 31439 & 31792 & 25261 & 4879 & 4185 & 12032 \\
\hline
\end{tabular}

Source: www.posindonesia.com (accessed on 12 October 2018, 16:25)

Table 3 explains that the number of deliveries by PT Pos Indonesia is not steady. Over the year, the deliveries experienced increased or decreased. This proves PT Pos Indonesis is less attractive for public in Indonesia. This could be due to a lack of or less satisfaction of the customer. The main thing that govern the customers satisfaction in the courier service business is to meet customer the needs and desires.

Research objectives that can be arranged are to find out the description of the service quality in the postal service Indonesia, to know the description of the postal delivery service customer satisfaction Indonesia, to find out how big the quality services on customer satisfaction service delivery Pos Indonesia.

\section{Research Method}

The research method is a step that is owned and conducted by researchers in the framework of investigation on the data that has been obtained. According to Sugiyono (2017), a research method is essentially a scientific way to get data with a specific purpose and usefulness. This research uses a type of descriptive and quantitative research with causal approach. According to Riduan (2010) in Effendi and Yuliati (2016), a descriptive research is a research directed to solving problems by means of exposing or describing what research results. According to Sugiyono (2011), a quantitative research method is a method that is based on the philosophy of positivism, used for researching on population or a particular sample, data collection using data analysis, research instruments of Quantitative/statistics, with the aim to test the hypothesis that has been established (Effendi and Yuliati 2016). Research methods used in this research is to disseminate questionnaire to respondents directly and via the Google form.

The operationalization variable is a way to measure a concept that in this case there are variables that directly affect and are affected, that is, variables that can cause other problems or situations occur or variable and conditions that are vary depending on the others. In accordance with the title of the thesis, that is the effect of the quality of the services on customer satisfaction PT. Pos Indonesia, then two variables of this study, namely: The quality of service 
as free variables $(\mathrm{X})$ and customer satisfaction as a bound variable (Y)

To conduct free and bound variables, do dissemination to a number of the respondents. The question form was developed or created based on the indicators that are used to evaluate if the quality of service has an impact on customer satisfaction. The second variable of research can be divided in several dimensions and indicators such as outlined in table 4 and 5.

According to Stemvelt (2004) in Effendi and Yuliati (2016) the quality of service concepts is a revolution of perception about the quality of the revolution thoroughly the unthinkable and became an idea so that its implementation can be formulated uyang tested again, to become a process dynamic, ongoing, continuously in meeting the customer satisfaction.

Table 4. Operationalization Variable - Quality of service (X)

\begin{tabular}{|c|c|c|c|}
\hline Dimensions & Indicator & Scale & No items \\
\hline \multirow[t]{6}{*}{ Tangible } & Level of comfort Lounge & Interval & 1 \\
\hline & Level spacious parking area & Interval & 2 \\
\hline & Toilet hygiene level & Interval & 3 \\
\hline & The level of cleanliness of lounges & Interval & 4 \\
\hline & The level layout queue & Interval & 5 \\
\hline & The rate of appearance of the officers mess & Interval & 6 \\
\hline \multirow[t]{4}{*}{ Realibility } & The level of Customer service hospitality & Interval & 7 \\
\hline & $\begin{array}{l}\text { The level of responsiveness employees in } \\
\text { receiving the complaint or complaints }\end{array}$ & Interval & 8 \\
\hline & The level of security guaranteed parking & Interval & 9 \\
\hline & The level of security in shipping guaranteed & Interval & 10 \\
\hline \multirow[t]{3}{*}{ Responsiveness } & $\begin{array}{l}\text { The level of responsibility of the officials of } \\
\text { the goods against damage }\end{array}$ & Interval & 11 \\
\hline & $\begin{array}{c}\text { The level of precision of the goods to } \\
\text { destination }\end{array}$ & Interval & 12 \\
\hline & $\begin{array}{c}\text { The level of communication ability with a } \\
\text { polite language }\end{array}$ & Interval & 13 \\
\hline \multirow[t]{2}{*}{ Assurance } & The level of ability to understand customers & Interval & 14 \\
\hline & $\begin{array}{l}\text { The level of ability to understand customer } \\
\text { expressions }\end{array}$ & Interval & 15 \\
\hline \multirow[t]{3}{*}{ Empathy } & $\begin{array}{c}\text { The level of understanding the customer's } \\
\text { needs }\end{array}$ & Interval & 16 \\
\hline & A good level of service from start to finish & Interval & 17 \\
\hline & $\begin{array}{c}\text { The ease of filing a complaint if contacted } \\
\text { within }\end{array}$ & Interval & 18 \\
\hline
\end{tabular}

Source: Data processing (2018).

According to Caroline, Christina Whidya (2011), customer satisfaction concept is people satisfied customers when the perceived service quality meet or even exceed the expectations of customers. Customers who experience dissatisfaction when quality of services are below their expectations. 
Table 5. Operationalization Variable - Customer satisfaction (Y)

\begin{tabular}{cccc}
\hline Dimensions & Indicator & Scale & No items \\
\hline $\begin{array}{c}\text { Stay true to a good level of } \\
\text { service }\end{array}$ & $\begin{array}{c}\text { The perceived Profit levels of } \\
\text { customer } \\
\text { The level of assurance employees } \\
\text { towards customers or prospective } \\
\text { customers }\end{array}$ & Interval & 19 \\
$\begin{array}{c}\text { Recommend product Level } \\
\text { wishes to recommend a friend }\end{array}$ & $\begin{array}{c}\text { The level of desire to recommend } \\
\text { through social media }\end{array}$ & Interval & 21 \\
$\begin{array}{c}\text { Willing to pay more Level; } \\
\text { customers loyalty }\end{array}$ & The tariff rates paid & Interval & 23 \\
$\begin{array}{c}\text { Provide input Level Assessment } \\
\text { given by customers }\end{array}$ & The level of ease in filing a complaint & Interval & 24 \\
& The level of grant of reward & Interval & 25 \\
\hline
\end{tabular}

Source: Data processing (2018).

The type of data used in this research is quantitative data. Quantitative data is the type of data that can be measured or calculated directly, in the form of information or explanations, expressed with numbers or shaped figures. The necessary quantitative data in this study is the data courier service market share in Indonesia, top brand index, data of courier services and data of production package shipping services of PT Pos Indonesia.

Data source derived from this research is a secondary data source. Secondary data source is data directly collected by the researchers as a support. The sources of data in this study are respondent responses to the questionnaire form.

Table 6. The Source and Type of Data

\begin{tabular}{cccc}
\hline No & Data & $\begin{array}{c}\text { Types Of } \\
\text { Data }\end{array}$ & The Data Source \\
\hline 1 & $\begin{array}{c}\text { The amount of data delivery Pos } \\
\text { Indonesia population of Karawang } \\
\text { Branch }\end{array}$ & Secondary & Pos Indonesia Annual Report \\
& $\begin{array}{c}\text { The amount of data delivery Pos } \\
\text { Indonesia population of Karawang } \\
\text { Branch }\end{array}$ & Secondary & $\begin{array}{c}\text { BPS (Statistics Indonesia) } \\
\text { Karawang }\end{array}$
\end{tabular}

Source: Data processing (2018).

According to Sugiyono (2017), population is the generalization of the object or subject who has certain qualities and characteristics set by the researchers to learn and then draw the conclusion. Based on the definition of the population of used in this research, it (this research) considers the population of Karawang in the year 2017 (with a total 2,316,489 people, as per data listed in the BPS Karawang). According to Sugiyono (2017), there is part of samples and characteristics shared by the population. When a population is large, and researchers may not learn all what there are on the population, for example, because of limited funding, effort and time, researchers can use samples taken from populations. Based on the understanding of the sample, the study examined 100 people. Those results had already been factored using the formula Slovin, and used simply to represent people in Karawang who ever or frequently use of postal services for Pos Indonesian. According to Sugiyono (2017), the technique of sampling is a technique to determine the sample that will be used in research. There are a lot of sampling 
techniques that can be used. The sampling technique used in this research is Purposive Sampling technique. This technique uses criteria that have been selected by researchers in selecting samples.

\section{Result and Discussion}

Data collection through questionnaire related to characteristics of the respondents based on gender is presented in the following table.

Table 7. Gender of Respondent

\begin{tabular}{cccccc}
\hline & & & & Valid & Cumulative \\
Valid & Male & 30 & 30 & 30 & 30 \\
& Women & 70 & 70 & 70 & 100 \\
& Total & 100 & 100 & 100 & \\
\hline
\end{tabular}

Source: Data processing (2018)

The table shows less than half of the respondents using postal service of PT Pos Indonesia are male and more than half are women.

Table 8. Profession of Respondent

\begin{tabular}{cccccc}
\hline & & Frequency & $\%$ & $\begin{array}{c}\text { Valid } \\
\text { Percent }\end{array}$ & $\begin{array}{c}\text { Cumulative } \\
\text { Percent }\end{array}$ \\
\hline Valid & Students & 45 & 45 & 45 & 45 \\
& Employees & 33 & 33 & 33 & 78 \\
& Housewife & 5 & 5 & 5 & 83 \\
& Other & 17 & 17 & 17 & 100 \\
& Total & 100 & 100 & 100 & \\
\hline
\end{tabular}

Source: Data processing (2018).

The table shows less than half of respondents ever or frequently used postal delivery service from PT Pos Indonesia are students or employees, while only small fraction of respondents who are housewives or having other professions.

Table 9. Respondent's Intensity Using the Service

\begin{tabular}{cccccc}
\hline & & Frequency & $\%$ & $\begin{array}{c}\text { Valid } \\
\text { Percent }\end{array}$ & $\begin{array}{c}\text { Cumulative } \\
\text { Percent }\end{array}$ \\
\hline Valid & Once & 44 & 44 & 44 & 44 \\
& 2-5 Times & 33 & 33 & 33 & 77 \\
& $6-$ 10 Times & 10 & 10 & 10 & 87 \\
& More than 10 Times & 13 & 13 & 13 & 100 \\
& Total & 100 & 100 & 100 & \\
\hline
\end{tabular}

Source: Data processing (2018).

The table above shows that almost $50 \%$ of respondents use of postal delivery service from PT Pos Indonesia only one time. Far below 50\% of respondents use of postal delivery service from PT Pos Indonesia $2-5$ times, while only small fraction of respondents use postal delivery service $5-10$ times or more than 10 times. 
Table 10. Regression Test Result

\begin{tabular}{ccc}
\hline Independent Variable & Coefficient & Significance \\
\hline Constant & 11.764 & 0.001 \\
QUALITY OF SERVICE & 0.434 & 0.000 \\
R & & 0.644 \\
R-Squared & & 0.415 \\
Adjusted R-Squared & 0.409 \\
Prob (F-Statistic) & 0.000
\end{tabular}

Source: Data processing (2018).

The results are known on the table's calculated value $t$, is the significance value 0.000 , then $\mathrm{h} 1$ is accepted, which means there is a real influence (significant) variable quality of service (X) against Complacency Customers (Y).

Table 11. One-Sample Kolmogorov-Smirnov Test

\begin{tabular}{ccc}
\hline \multicolumn{2}{c}{$\mathrm{N}$} & 100 \\
Normal Parameters ${ }^{\mathrm{a}, \mathrm{b}}$ & Mean & 0.000 \\
Most Extreme & Std. Deviation & 435 \\
Differences & Absolute & 0.048 \\
& Positive & 0.048 \\
Test Statistic & Negative & 0.044 \\
Asymp. Sig. (2-tailed) & 0.048 \\
a. Test distribution is Normal. & $0.200^{\mathrm{c}, \mathrm{d}}$ \\
b. Calculated from data. & \\
c. Lilliefors Significance Correction. \\
d. This is a lower bound of the true significance. \\
Source: Data processing (2018).
\end{tabular}

Based on SPSS output, it can be noted that the value of significance of 0.200 is more than 0.05 , such that it can be noted that the data is in the test of Gaussian.

Table 12. Reliability Statistics

\begin{tabular}{ccc}
\hline Variables & Cronbach's Alpha & N of Items \\
\hline Quality Of Services (X) & 0.914 & 18 \\
Customer Satisfaction (Y) & 0.804 & 12 \\
\hline
\end{tabular}

Reliability test based on the value of the variable gives result for alpha-values for $\mathrm{X}$ and $\mathrm{Y}$. All variables have produced alpha-value $>0.6$, so it can be noted that all the instruments in this study is within reliability criteria.

This research aims to know the effect of the quality of service (Variable X) on customer satisfaction (Variable Y) in PT Pos Indonesia, Karawang Branch. Based on the results from data processed using the IBM SPSS statistics software 24, the known multiple regression test results from the Model Summary table explains the magnitude of the value of the correlation or relationship (R) of 0.644 and describes the magnitude of the influence of presentation of free variables against a variable called the coefficients of determination that is the result of squaring $R\left(R^{2}\right)$. SPSS output results coefficients of determination (R-Squared) of 0,415 . This means, the effect of free variables (quality of service) against bound variables (customer satisfaction) is amounting to $41.5 \%$, while the rest is affected by other variables. Test Anova Results output acquired SPSS value for F of 69.627 with a degree of probability (Sig) 0000 0.05, then < 
regression model can be used to predict the variable customer satisfaction, whereas on the basis of test of reliability obtained the value of the result of the variable $\mathrm{X}$ and $\mathrm{Y}$ all his produce value $>0.6$ so it can be noted that all the instruments in this research is within reliability criteria.

\section{Conclusion}

Based on the results of research that has been done, then the conclusion can be drawn as. follows: first, there is a positive and significant image of the quality of service on the PT Pos Indonesia's postal service. This means the better quality of service is provided the more number of consumers use PT Pos Indonesia's delivery service will grow. Second, There is a significant and positive image of customer satisfaction to PT Pos Indonesia's postal service. This means the more customers indicate the higher the satisfaction of customers who use the service of PT Pos Indonesia.

There is a significant and positive effect of the quality of service on customer satisfaction PT Pos Indonesia's delivery service. This means the better quality of service is provided then the higher the customer satisfaction is on PT Pos Indonesia's delivery service.

\section{References}

Azis A. 2016. Pengauh Kualitas Pelayanan terhadap Kepercayaan dan Loyalitas Konsumen (Studi Kasus pada Pengguna Jasa Pengiriman Paket PT Pos Indonesia (Persero) [Skripsi]. Yogjakarta: Universitas Negeri Yogjakarta.

Effendi J, Yuliati AL. 2016. Pengaruh Kualitas Pelayanan terhadap Kepuasan Pelanggan pada JNE Cabang Bandung. DeReMa Jurnal Manajemen. 11(2): 265-289.

Indah YR, Suryoko S. 2015. Pengaruh Kualitas Pelayanan terhadap Kepuasan Pelanggan (Studi kasus pada Pengguna Jasa Pengiriman Barang di Kantor Pos Semarang). Jurusan Ilmu Administrasi Bisnis Universitas Diponegoro. 1:1-11.

Pos Indonesia. 2018. Jakarta: Pos Indonesia. [Cited in 2018 October 21]. Available from www.posindonesia.co.id.

Rahmayanti PR, Suryawardani B. 2014. Pengaruh Kualitas Pelayanan Terhadap Kepuasan Pelanggan Pada PT. JNE Perwakilan Kawaluyaan Tahun 2014. Journal Banking and Management. 4(2): 2252-8520.

Sugiyono. 2011. Metode Penelitian Kuantitaif Kualitatif dan $R \&$ \& . Bandung: Alfabeta.

Sulityawati NMA, Seminari NK. 2015. Pengaruh Kualitas Pelayanan Terhadap Kepuasan Pelanggan Restoran Indus Ubud Gianyar. E-Jurnal Manajemen Unud. 4(8): 23182332. 